Reprod. Nutr. Dévelop., 1982, 22 (2), 387-394.

\title{
Microbial flora in the digestive tract and action of lactose on mineral metabolism
}

\author{
Claude ANDRIEUX, E. SACQUET, L. GUEGUEN $\left({ }^{*}\right)$, \\ Laboratoire des Animaux sans Germes, C.N.R.S., \\ (*) Station de Recherches de Nutrition, I.N.S.A., \\ 78350 Jouy-en-Josas, France.
}

Summary. Germ-free (GF) and conventional (CV) adult rats were given for 4 weeks a semi-synthetic diet containing 10 p. 100 lactose (L) or no lactose (LO).

- The axenic state had an unfavourable effect on sodium and potassium absorption. On the contrary, it increased the absorption and retention of calcium, phosphorus and magnesium.

- The favourable effect of lactose on magnesium metabolism was not different in GF and $\mathrm{CV}$ rats. On the contrary, lactose increased the absorption and retention of phosphorus and calcium more in GF than in CV animals. It augmented the amount of calcium present in a soluble, ultrafiltrable form in the caecum of only the GF rats. These results are discussed and compared to previous data on younger rats. They lead to the hypothesis that the voluminous caecum of the GF rat is the site of a calcium absorption which is accentuated by presence of lactose in the diet.

\section{Introduction.}

It has been shown that the microbial flora of the digestive tract acts on mineral metabolism in the rat, modifying the effects of the mode of diet sterilization (Andrieux, Guéguen and Sacquet, 1979), of Maillard's reaction products (Andrieux, Sacquet and Guéguen, 1980) and of lactose (Andrieux, Guéguen and Sacquet, 1980). These studies were carried out in 6-week old rats. Before trying to determine how the microflora produces these effects, two points must be considered : (i) lactose may not have the same effect in adult rats as in 6week old rats, (ii) the previous results were obtained by comparing GF and CV rats; knowing that the caecum is more voluminous in the former rats, it is necessary to determine the role of that organ in mineral absorption, particularly that of calcium.

The present paper reports a comparative study of the absorption of different minerals in adult germ-free and conventional rats and the availability of caecal calcium. 


\section{Material and methods.}

We compared germ-free (GF) and conventional (CV) rats receiving a diet containing either 10 p. 100 lactose (L) or no lactose (LO). These rats were divided into groups GFLO, GFL, CVLO and CVL.

Diet and animals. - The composition of the basic diet is given in table 1. Lactose was introduced by replacing $10 \mathrm{p} .100$ of the starch by its equal weight in lactose. The diet was put into polystyrene, vacuum-sealed bags, then sterilized by gamma irradiation at 4 megarads.

\section{TABLE 1}

Diet composition (p. 100)

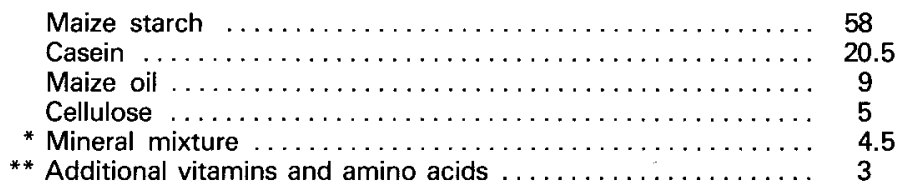

* The mineral mixture includes (in $\mathrm{g}$ per $100 \mathrm{~g}$ of diet) : Calcium carbonate 1.3 ; monocalcium phosphate 0.55 ; dipotassium phosphate 1.125 ; disodium phosphate 0.5 ; sodium chloride 0.25 ; magnesium sulfate 0.6 ; iron citrate 0.1 ; zinc sulfate 0.025 ; manganese sulfate 0.040 ; copper sulfate 0.006 ; potassium iodide 0.005 ; cobalt chloride 0.001 . The mineral composition of each preparation was controlled by assay. The complete diet contained (in $\mathrm{mg} / \mathrm{g})$ a mean of $\mathrm{Ca}: 8.2 ; \mathrm{P}: 6.7 ; \mathrm{K}: 5.6 ; \mathrm{Na}$ : $3.2 ; \mathrm{Mg}: 0.7$.

** In Andrieux, Guéguen and Sacquet, 1980.

Each experimental group contained 8 male Fischer 344 rats. At 3 months of age, the rats, previously fed a commercial diet, were given either diet (L) or (LO). At 4 months, they were isolated in metabolism crates for one week and their mineral balances were recorded for 8 successive days.

Biochemical methods. - The caecal contents were centrifuged for $15 \mathrm{~min}$ at $35000 \times \mathrm{g}$. The supernatant obtained was ultrafiltered on an Amicon CF $50 \mathrm{~A}$ cone which retained molecules of more than $50000 \mathrm{MW}$. The diets, feces, urine and caecal contents (pellet, supernatant and ultrafiltrate) were then dry-ashed at $550^{\circ} \mathrm{C}$ for $16 \mathrm{~h}$.

The ash was dissolved in $\mathrm{HCl}$, which was evaporated then redissolved in 10 p. $100 \mathrm{HNO}_{3}$.

The calcium, sodium and potassium in the diets, feces and urine were assayed by flame photometry (Eppendorf apparatus). The calcium in the cecal contents was assayed by atomic absorption spectrometry. The magnesium was assayed by atomic absorption spectrometry (IL 151 apparatus). Phosphorus was determined after formation of a compound with ammonia vanadomolybdate. 
Modes of expression of results and statistical ana/ysis. - The results were expressed in $\mathrm{mg}$ of the element absorbed and retained per day and in p. 100 of the quantity ingested. Each result was shown by the mean \pm SD. Analysis of variance was used for statistical comparison : the effect of each factor - flora or lactose - was determined as well as that of their interaction (Snedecor and Cochran, 1957).

\section{Results.}

The rats of the various lots showed no significant body weight differences $\mathrm{GFL}=303 \pm 21 \mathrm{~g} ; \mathrm{GFL}=297 \pm 25 \mathrm{~g} ; \mathrm{CVLO}=304 \pm 16 \mathrm{~g} ; \mathrm{CVL}=307 \pm 16 \mathrm{~g}$ ) nor did the amounts of the diet ingested during the balance period. The two modes of expressing the results of mineral balances thus gave similar values.

Mineral balances (tables 2, 3, 4, 5, 6). - The axenic state increased absorption $(P<0.001)$, urinary excretion $(P<0.05)$ and retention $(P<0.001)$ of calcium, phosphorus and magnesium. Sodium $(P<0.01)$ and potassium

TABLE 2

Calcium balance

\begin{tabular}{|c|c|c|c|c|c|c|c|}
\hline \multirow{2}{*}{$\frac{\text { Rats (8 per group) }}{\text { Diet }}$} & \multicolumn{2}{|c|}{ Conventional (CV) } & \multicolumn{2}{|c|}{ Germ-free (GF) } & \multicolumn{3}{|c|}{ Variance analysis (F-test) } \\
\hline & LO & L & Lo & L & $\begin{array}{l}\text { Flora } \\
\text { (F) }\end{array}$ & $\begin{array}{l}\text { Lactose } \\
\text { (L) }\end{array}$ & $\begin{array}{l}\text { Interaction } \\
\text { (F-L) }\end{array}$ \\
\hline$\ldots$ (mg/day) & $92.8 \pm 8.1$ & $102.4 \pm 10.1$ & $100.4 \pm 9.0$ & $99.9 \pm 10.9$ & & & \\
\hline retion " & 75.0 & $77.7 \pm 8.0$ & & $57.8 \pm 6$ & ** & ** & ** \\
\hline & $17.8 \pm 2.6$ & $24.7 \pm$ & $24.7 \pm 6.5$ & $42.1 \pm$ & *** & *** & ** \\
\hline Urinary excretion & $0.6+0.1$ & $0.7+$ & $1.3+0.5$ & $3.1+$ & *** & $* *$ & ** \\
\hline Retained .... & $17.2 \pm 2.6$ & $24.0 \pm$ & $23.4 \pm 6.6$ & $39.0 \pm$ & **** & *** & * \\
\hline (\% intake) & $19.2 \pm 2.6$ & $24.1 \pm$ & $24.7 \pm 5.2$ & $40.1 \pm 6.7$ & *** & ** & ** \\
\hline Retained & $18.5 \pm 2.6$ & $23.4 \pm 2.4$ & $23.4 \pm 5.7$ & $38.0 \pm 5.2$ & *** & *** & ** \\
\hline
\end{tabular}

Results are shown by $(\mathrm{m} \pm \mathrm{SD})$. ${ }^{* * *} \mathrm{P}<0.001 ;{ }^{* *} \mathrm{P}<0.01 ;{ }^{*} \mathrm{P}<0.05$.

TABLE 3

Phosphorus balance

\begin{tabular}{|c|c|c|c|c|c|c|c|}
\hline \multirow{2}{*}{$\frac{\text { Rats (8 per group) }}{\text { Diet }}$} & \multicolumn{2}{|c|}{ Conventional (CV) } & \multicolumn{2}{|c|}{ Germ-free (GF) } & \multicolumn{3}{|c|}{ Variance analysis (F-test) } \\
\hline & LO & $L$ & Lo & $\mathbf{L}$ & $\begin{array}{l}\text { Flora } \\
\text { (F) }\end{array}$ & $\begin{array}{l}\text { Lactose } \\
\text { (L) }\end{array}$ & $\begin{array}{l}\text { Interaction } \\
(F-L)\end{array}$ \\
\hline$\ldots .(\mathrm{mg} /$ day $)$ & $75.8 \pm 6.4$ & $83.6 \pm 8.2$ & $82.1 \pm 7.4$ & $81.6 \pm 8.9$ & & & \\
\hline Fecal excretion $\gg$ & $42.5 \pm 2.1$ & $44.6 \pm 5.0$ & $38.8 \pm 5.6$ & $28.9 \pm 3.3$ & *** & $* *$ & ** \\
\hline Absorbed .... & $33.3 \pm 4.8$ & $39.0 \pm 3.9$ & $43.3 \pm 6.4$ & $53.3 \pm 7.8$ & ** & ** & * \\
\hline Urinary excretion & $17.5 \pm 2.6$ & $18.3 \pm 1.7$ & $23.9 \pm 2.9$ & $22.4 \pm 3.3$ & $*$ & & \\
\hline Retained $\ldots . . \quad »$ & $15.8 \pm 3.8$ & $20.7 \pm 3.8$ & $19.4 \pm 3.6$ & $30.9 \pm 4.1$ & $* * *$ & $* * *$ & * \\
\hline Absorbed ... (\% intake) & $43.3 \pm 3.4$ & $46.7 \pm 2.5$ & $52.7 \pm 4.1$ & $65.6 \pm 3.7$ & *** & *** & *** \\
\hline Retained ... $n$ & $20.9 \pm 3.6$ & $24.8 \pm 3.5$ & $23.6 \pm 3.4$ & $38.0 \pm 4.7$ & $* * *$ & $* * *$ & *** \\
\hline
\end{tabular}

Results are shown by $(\mathrm{m} \pm \mathrm{SD}){ }^{* * *} \mathrm{P}<0.001 ;{ }^{*} \mathrm{P}<0.01 ;{ }^{*} \mathrm{P}<0.05$. 
TABLE 4

Magnesium balance

\begin{tabular}{|c|c|c|c|c|c|c|c|}
\hline \multirow{2}{*}{$\frac{\text { Rats (8 per group) }}{\text { Diet }}$} & \multicolumn{2}{|c|}{ Conventional (CV) } & \multicolumn{2}{|c|}{ Germ-free (GF) } & \multicolumn{3}{|c|}{ Variance analysis (F-test) } \\
\hline & LO & L & LO & $\mathrm{L}$ & $\begin{array}{l}\text { Flora } \\
\text { (F) }\end{array}$ & $\begin{array}{l}\text { Lactose } \\
\text { (L) }\end{array}$ & $\begin{array}{c}\text { Interaction } \\
(F-L)\end{array}$ \\
\hline Intake $\ldots \ldots$...(mg/day) & $7.92 \pm 0.66$ & $8.74 \pm 0.85$ & $8.57 \pm 0.77$ & $8.52 \pm 0.94$ & & & \\
\hline Fecal excretion " & $4.59 \pm 0.45$ & $4.24 \pm 0.44$ & $3.39 \pm 0.54$ & $2.31 \pm 0.41$ & *** & * & \\
\hline Absorbed .... " & $3.33 \pm 0.59$ & $4.50 \pm 0.49$ & $5.18 \pm 0.89$ & $6.21 \pm 0.8$ & *** & ** & \\
\hline Urinary excretion " & $1.96 \pm 0.19$ & $2.55 \pm 0.29$ & $3.44 \pm 0.57$ & $3.91 \pm 0.52$ & ** & & \\
\hline Retained ...." & $1.37 \pm 0.54$ & $1.95 \pm 0.51$ & $1.74 \pm 0.56$ & $2.31 \pm 0.33$ & *** & ** & \\
\hline Absorbed .... (\% intake) & $41.9 \pm 5.0$ & $51.5 \pm 2.2$ & $60.4 \pm 5.4$ & $72.8 \pm 4.9$ & $* * *$ & $* * *$ & \\
\hline Retained ..." & $17.1 \pm 5.8$ & $22.3 \pm 4.5$ & $20.4 \pm 5.6$ & $27.1 \pm 2.0$ & ** & ** & \\
\hline
\end{tabular}

Results are shown by $(\mathrm{m} \pm \mathrm{SD}) .{ }^{* *} \mathrm{P}<0.001 ;{ }^{*} \mathrm{P}<0.01 ;{ }^{*} \mathrm{P}<0.05$.

TABLE 5

Sodium balance

\begin{tabular}{|c|c|c|c|c|c|c|c|}
\hline Rats (8 per group) & \multicolumn{2}{|c|}{ Conventional (CV) } & \multicolumn{2}{|c|}{ Germ-free (GF) } & \multicolumn{3}{|c|}{ Variance analysis (F-test) } \\
\hline Diet & LO & $\mathbf{L}$ & LO & $\mathbf{L}$ & $\begin{array}{l}\text { Flora } \\
\text { (F) }\end{array}$ & $\begin{array}{l}\text { Lactose } \\
\text { (L) }\end{array}$ & $\begin{array}{l}\text { Interaction } \\
\text { (F-L) }\end{array}$ \\
\hline$\ldots \ldots \ldots(\mathrm{mg} /$ day $)$ & $36.2 \pm 3.2$ & $40.0 \pm 3.8$ & $39.2 \pm 3.5$ & $39.0 \pm 4.3$ & & & \\
\hline Fecal excretion " & $1.4 \pm 0.5$ & $2.0 \pm 1.1$ & $9.3 \pm 1.5$ & $8.9 \pm 0.9$ & $* * *$ & & \\
\hline Absorbed .... & $34.8 \pm 2.8$ & $38.0 \pm 3.4$ & $29.9 \pm 2.7$ & $30.1 \pm 5.2$ & ** & & \\
\hline Urinary excretion & $27.6 \pm 3.0$ & $28.6 \pm 1.8$ & $21.9 \pm 3.1$ & $21.3 \pm 5.6$ & ** & & \\
\hline Retained $\ldots .$. & $7.2 \pm 3.1$ & $9.4 \pm 3.8$ & $8.0 \pm 2.5$ & $8.8 \pm 2.9$ & & & \\
\hline Absorbed ... (\% intake) & $96.2 \pm 1.3$ & $94.9 \pm 1.7$ & $75.9 \pm 5.9$ & $78.0 \pm 3.0$ & ** & & \\
\hline Retained ... " & $19.9 \pm 8.0$ & $23.1 \pm 8.3$ & $20.5 \pm 5.3$ & $22.1 \pm 5.1$ & & & \\
\hline
\end{tabular}

Results are shown by $(\mathrm{m} \pm \mathrm{SD}) .{ }^{* *} \mathrm{P}<0.001 ;{ }^{* *} \mathrm{P}<0.01$

TABLE 6

Potassium balance

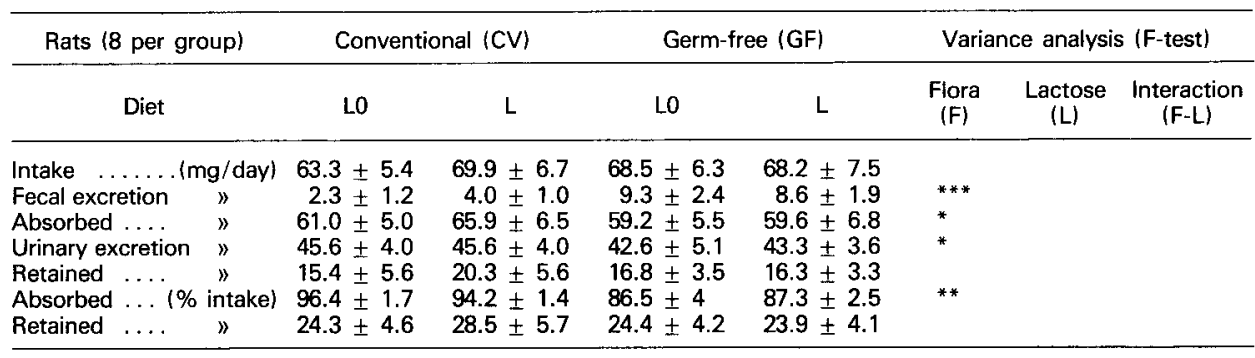

Results are shown by $(\mathrm{m} \pm \mathrm{SD}) .{ }^{* * *} \mathrm{P}<0.001 ;{ }^{* *} \mathrm{P}<0.01 ;{ }^{*} \mathrm{P}<0.05$. 
$(P<0.05)$ absorption was significantly lower in GF than in CV rats, but this difference in absorption was compensated by a lower urinary excretion.

The lactose diet increased the absorption of calcium, phosphorus and magnesium. It augmented urinary excretion of magnesium and calcium but had no effect on that of phosphorus. The retention of these three minerals was significantly increased by lactose $(P<0.001$ for calcium and phosphorus ; $P<0.01$ for magnesium). Sodium and potassium absorption and retention were not significantly modified.

The effect of lactose on the absorption of phosphorus and calcium was more pronounced in GF than in $C V$ rats $(P<0.05$ for phosphorus ; $P<0.01$ for calcium). Urinary calcium excretion increased more in GF rats without affecting retention. Lactose increased calcium and phosphorus retention more in GF than in $\mathrm{CV}$ rats (significant lactose-flora interaction : $P<0.01$ for calcium ; $P<0.05$ for phosphorus).

There was no lactose-flora interaction concerning the absorption and retention of magnesium, sodium or potassium.

Distribution of caecal calcium (table 7). - In GF compared to CV rats, the caecal weight, the supernatant, the total calcium content and the calcium present in the supernatant, as well as the ultrafiltrable calcium, were higher $(P<0.001)$. Dietary lactose produced variations which were different in $\mathrm{CV}$ and $\mathrm{GF}$ rats (significant lactose-flora interaction). In CV rats, it increased caecal weight and did not modify the other characteristics ; in GF rats, the reverse was observed. It decreased the total calcium present in the cecum and increased all the other factors, such as proportion of supernatant, amount of calcium and ultrafiltrable calcium in the supernatant.

TABLE 7

Calcium distribution in the cecum

\begin{tabular}{|c|c|c|c|c|c|c|c|c|}
\hline \multirow{2}{*}{$\frac{\text { Rats }(8 \text { per group) }}{\text { Diet }}$} & \multicolumn{2}{|c|}{ Conventional (CV) } & \multicolumn{3}{|c|}{ Germ-free (GF) } & \multicolumn{3}{|c|}{ Variance analysis (F-test) } \\
\hline & Lo & $L$ & & 0 & L & $\begin{array}{l}\text { Flora } \\
\text { (F) }\end{array}$ & $\begin{array}{l}\text { Lactose } \\
\text { (L) }\end{array}$ & $\begin{array}{l}\text { Interaction } \\
\quad(F-L)\end{array}$ \\
\hline $\begin{array}{l}\text { Caecal weight }(g) \ldots \ldots \\
\text { Caecal supernatant ..... } \\
\text { (p. } 100 \text { of fecal contents) }\end{array}$ & $\begin{array}{r}3.9 \pm 0.4 \\
28.3 \pm 1.8\end{array}$ & $\begin{array}{r}5.2 \pm 0.6 \\
31.2 \pm 1.9\end{array}$ & $\begin{array}{l}16.9 \\
53.7=\end{array}$ & $\begin{array}{l} \pm \quad 1.2 \\
\pm \quad 2.3\end{array}$ & $\begin{array}{l}16.4 \pm 1.9 \\
77.5 \pm 2.9\end{array}$ & $\begin{array}{l}* * * \\
* * *\end{array}$ & ** & *** \\
\hline $\begin{array}{l}\text { Calcium in contents }(\mathrm{mg}) \\
\text { Calcium in supernatant }\end{array}$ & $31.1 \pm 3.4$ & $30.5 \pm 4.8$ & 114.1 & \pm 11.2 & $70.3 \pm 2.8$ & $* * *$ & ** & $* * *$ \\
\hline $\begin{array}{l}\text { (mg) } \ldots . . . \ldots \ldots \ldots \\
\text { Ultrafiltrable calcium (mg) }\end{array}$ & $\begin{array}{l}0.74 \pm 0.09 \\
0.46 \pm 0.07\end{array}$ & $\begin{array}{l}0.67 \pm 0.1 \\
0.5 \pm 0.1\end{array}$ & $\begin{array}{l}3.1 \\
2.4\end{array}$ & $\begin{array}{l}0.4 \\
0.1\end{array}$ & $\begin{array}{l}5.5 \pm 0.4 \\
4.9 \pm 0.6\end{array}$ & $\begin{array}{l}* * * \\
* * *\end{array}$ & ** & $* * *$ \\
\hline
\end{tabular}

Results are shown by $(\mathrm{m} \pm \mathrm{SD}) .{ }^{* *} \mathrm{P}<0.001 ;{ }^{* *} \mathrm{P}<0.01$

\section{Discussion.}

In the present experiment we used adult rats. In a previous experiment we used 6-week old rats (Andrieux, Guéguen and Sacquet, 1980). The effects of flora 
and lactose on the metabolism of $\mathrm{Mg}, \mathrm{Na}$ and $\mathrm{K}$ were similar in adult and young rats. On the contrary, the effects of these two factors on calcium and phosphorus metabolism varied with age.

Thus, lactose increased the absorption and retention of these minerals in young and adult $\mathrm{CV}$ rats, while in GF animals, it had no effect in the young but caused a high increase in absorption and retention in adults. This situation may be due to the fact that the absorption level was already very high (45 p. 100 of ingested $\mathrm{Ca}$ and 59 p. 100 of ingested P) in the young GF rats and could not increase more (Andrieux, Guéguen and Sacquet, 1980). It has been shown that, due to the effect of age, the influence of vitamin $D$ decreases in the adult rat (Armbrecht et al., 1979 ; Armbrecht, Zenser and Davis, 1980), while the action of lactose persists (Dupuis and Fournier, 1964). Moreover, the effect of vitamin D may be greater in GF than in CV rats; this proposition agrees with the high values of calcium absorption and retention in young GF rats and with the works of Reddy (1972) showing that Ca-BP and alkaline phosphatase levels are higher in GF rats.

Although the way in which lactose affects calcium absorption has been thoroughly studied, it is still being debated (Ali and Evans, 1973 ; Wasserman and Taylor, 1976 ; Armbrecht and Wasserman, 1976 ; Fournier and Dupuis, 1975 ; Dupuis, Fournier and Fournier, 1976). Some new hypotheses may be presented. Recently, Meslin and Sacquet (1981) showed that lactose increases cell production in the ileal crypts of GF rat but decreases it in $\mathrm{CV}$ rat ; lactose augments the number of cells in the ileal villi in both types of rats but this increase is greater in GF than in CV rats. These modifications might result in a variation in the absorption of some minerals.

Whatever the mechanism involved, the fact that lactose has such a spectacular effect on the absorption of calcium, phosphorus and magnesium in adult GF rats definitely demonstrates that the flora is not requisite to in vivo lactose action. These results resolve a debate which has been going on for many years. In fact, Bergheim's (1926) hypothesis, according to which the effect of lactose on mineral absorption would be due to the microbial fermentation of lactose, has been attacked by many authors who showed that neither the addition of antibiotics to the diet (Dupuis and Fournier, 1958; Wasserman and Lengeman, 1960) nor the excision of the caecum (Fournier, Susbielle and Dupuis, 1960), the main site of lactic fermentation, modified the action of lactose. But other workers have recently maintained that such absorption does occur in CV rats fed with a lactose diet (Demigné, Rémésy and Rayssiguier, 1980).

Because this lactose effect is more marked in GF than in CV rats, it is evident that lactose acts more by itself than by the metabolites of intestinal bacteria. The differences observed could be mainly due to the more or less important amounts of lactose in the digestive tract. In fact, the lactasic activity of the intestinal mucosa being reduced in weaned rat (Reddy et al., 1968 ; Leichter, 1973 ; Pansu, Bellaton and Bosshard, 1978), lactose hydrolysis is mostly insured by the bacterial flora (Adrian and Frangne, 1978). Dahlquist (1974) showed that microbial fermentation of lactose takes place immediately in the stomach and Kim et al. (1978) estimate that 70 p. 100 of the ingested lactose is hydrolized in the small intestine. 
The amount of lactose in the intestinal medium should thus be higher in the GF than in the $\mathrm{CV}$ rats at all levels of the digestive tract.

To the two hypotheses proposed above, we can add a third one explaining why lactose acts differently on calcium and phosphorus metabolisms in GF and $\mathrm{CV}$ rats. The voluminous caecum of GF rats contains more soluble calcium than that of CV rats, and that amount of soluble calcium is increased still more by the lactose. This increase in soluble calcium in GFLO rats compared to CVLO rats may result from the mere increase in caecal weight. But the GFL rats had a higher amount of soluble calcium in that organ, although its weight remained similar. Therefore, this increase was caused by the lactose itself ; it did not take place in $\mathrm{CVL}$ rats : the ratio of soluble to total calcium is CVLO $=2.4, \mathrm{CVL}=2.2$, $\mathrm{GFLO}=2.7, \mathrm{GFL}=7.8$. Of course, the fact that the caecum contained more soluble $\mathrm{Ca}$ does not mean that that $\mathrm{Ca}$ was absorbed in either the caecum or the colon, but it does mean that such a possibility exists. The effectiveness of this absorption is being investigated.

Reçu en août 1981.

Accepté en novembre 1981.

Résumé. Des rats adultes axéniques (GF) et holoxéniques (CV) reçoivent pendant 4 semaines un aliment semi-synthétique conteriant (L) ou non (LO) 10 p. 100 de lactose. - L'ètat axénique a un effet défavorable sur l'absorption du sodium et du potassium. II augmente, au contraire, l'absorption et la rétention du calcium, du phosphore et du magnésium.

- L'effet favorable du lactose sur le métabolisme du magnésium n'est pas différent chez les rats axéniques et chez les holoxéniques. Par contre, le lactose augmente davantage l'absorption et la rétention du phosphore et du calcium chez les rats axéniques que chez les holoxéniques. II augmente la quantité de calcium présent sous forme soluble et ultrafiltrable dans le caecum des seuls rats axéniques. Ces résultats sont discutés et comparés aux résultats précédemment obtenus chez des rats plus jeunes. Ils conduisent à l'hypothèse que le volumineux caecum du rat axénique est le lieu d'une absorption non négligeable de calcium, absorption accrue par la présence de lactose dans l'aliment.

\section{References}

ADRIAN J., FRANGNE R., 1978. Rôle de la flore digestive dans l'adaptation du rat à une alimentation lactosée. J. int. Vitaminol. Nutr., 48, 170-176.

ALI R., EVANS J. L., 1973. Lactose and calcium metabolism. A review. J. agric. Univ. P. R., 57, 149-164.

ANDRIEUX C., GUÉGUEN L., SACQUET E., 1979. Influence du mode de stérilisation des aliments sur l'absorption des minéraux chez le rat axénique et holoxénique. Ann. Nutr. Alim., 33. 1257-1284.

ANDRIEUX C., GUÉGUEN L., SACQUET E., 1980. Effects of lactose and mode of sterilization of a lactose diet on mineral metabolism in germ-free and conventional rats. Reprod. Nutr. Dévelop., 20, 119-138.

ANDRIEUX C., SACQUET E., GUÉGUEN L., 1980. Interactions between Maillard's reaction products, the microflora of the digestive tract and mineral metabolism. Reprod. Nutr. Dévelop., 20, 1061-1069.

ARMBRECHT H. J., WASSERMAN R. H., 1976. Enhancement of $\mathrm{Ca}^{++}$uptake by lactose in the rat small intestine. J. Nutr., 106, 1265-1271. 
ARMBRECHT H. J., ZENSER T. V., BRUNS E. H., DAVIS B. B., 1979. Effect of age on intestinal calcium absorption and adaptation to dietary calcium. Am. J. Physiol., 236, E769-E774.

ARMBRECHT H. J., ZENSER T. V., DAVIS B. B., 1980. Effect of vitamin D metabolites on intestinal calcium absorption and calcium binding protein in young and adult rats. Endocrinology, 106, 469-475.

BERGHEIM O., 1926. Intestinal chemistry. $V$ : Carbohydrates and calcium and phosphorus absorption. J. biol. Chem., 70, 35-45.

DAHLQVIST A., THOMSON D. L., 1964. The digestion and absorption of lactose by the intact rat. Acta. physiol. scand., 61, 20-33.

DEMIGNE C., REEMÉSY C., RAYSSIGUIER Y., 1980. Effect of fermentable carbohydrates on volatile fatty acids, ammonia and mineral absorption in the rat caecum. Reprod. Nutr. Dévelop., 20, 1351-1360.

DUPUIS Y., FOURNIER P. L., 1958. Influence de l'administration d'auréomycine sur la manifestation des effets biologiques du lactose. C. R. Acad. Sci. Paris, 246, 2931-2934.

DUPUIS Y., FOURNIER P. L., 1964. Etude comparée de l'action de la vitamine $D$ et du lactose sur les échanges calciques durant la vie du rat. C. R. Acad. Sci. Paris, 258, 2906-2909.

DUPUIS Y., FOURNIER A., FOURNIER P., 1976. Etude, au niveau de la muqueuse jéjunale, des effets de divers composés glucidiques sur l'activité de quelques enzymes localisées dans les bordures en brosse, accroissement d'activité phosphatasique. C. R. Soc. Biol., 170, 739744.

FOURNIER P., DUPUIS Y., 1975. La modulation de l'absorption intestinale du calcium. J. Physiol., 70, 479-491.

FOURNIER P., SUSBIELLE H., DUPUIS Y., 1960. Propriétés biologiques du lactose et fermentations intestinales. Cas de I'ablation du caecum. C. R. Acad. Sci. Paris, sér. D, 250, 11111113.

KIM K. I., BENEVENGA N. J., GRUMMER R. H., 1978. Estimation of the fraction of the lactose in a high lactose diet available for fermentation in the caecum and colon of the rat. $J$. Nutr., 108, 79-89.

LEICHTER J., 1973. Effect of dietary lactose on intestinal lactose activity in young rats. J. Nutr., 103, 392-396.

MESLIN J. C., SACQUET E., RIOTTOT M., 1981. Effect of various modifications in the diet on ileal epithelium renewal in germ-free and conventional rats. Reprod. Nutr. Dévelop., 21, 651659.

PANSU D., BELLATON C., BOSSHARD A., 1978. Effect of lactose feeding on cell renewal, disaccharidase activity and calcium-binding protein content in the intestinal mucosa of rats. Ann. Biol. anim. Bioch. Biophys., 18, 127-132.

REDDY B. S., 1972. Studies on the mechanism of calcium and magnesium absorption in germ-free rats. Arch. Bioch. Biophys., 149, 15-21.

REDDY B. S., PLEASANTS J. R., WOSTMANN B. S., 1968. Effect of dietary carbohydrates on intestinal disaccharidases in germ-free and conventional rats. J. Nutr., 95, 413-419.

SNEDECOR G. W., COCHRAN W. G., 1957. Méthodes statistiques. $6^{\circ}$ éd. ACTA. Paris, 379-424.

WASSERMAN R. H., LENGEMANN E. W., 1960. Further observations on lactose stimulation of the gastrointestinal absorption of calcium and strontium in the rat. J. Nutr., 70, 377-384.

WASSERMAN R. H., TAYLOR A. N., 1976. Intestinal absorption of calcium, 379-393. In COMAR C. L., BRONNER F., Mineral metabolism. Vol. V, Acad. Press. New York. 